\title{
Occurrence of finfish communities in trawl hauls of Atlantic Ocean in Badagry coast, Nigeria
}

\author{
E. F. MYADE *, M. O. OYEBANJI, E. O. OLUWAJOBA, A. B. WILLIAMS, \\ B. C. MBAWUIKE, N. AJUONU, G. W. OLAKUNLE, O. O. ADEGBILE, \\ A. Y. GADZEKPO, M. U. UMUNNAKWE and M.A. ABASS
}
Nigeria Institute for Oceanography and Marine Research, No 3 Wilmot Point Road, P. M. B. 12729 Victoria Island - Lagos State, Nigeria.
*Corresponding author; E-mail: myfarai@yahoo.com

\begin{abstract}
Thirteen trawl hauls were conducted at depths ranging from $10 \mathrm{~m}-100 \mathrm{~m}$. Fifty six finfish families were observed, comprising ninety seven species from eighty two genera. Ten commercially important finfish families were identified out of which the Haemulidae had the highest number of occurrence and distribution with catch per unit area (CPUA) of $36.17 \mathrm{Kg} / \mathrm{Km}^{2}$. The Carangidae with CPUA of $22.09 \mathrm{Kg} / \mathrm{Km}^{2}$ was the lowest in abundance and distribution of the important finfish families. The total biomass estimate of finfish from the entire survey area under investigation was 440 tons $(\mathrm{t})$. The middle stratum, $\mathrm{S} 2(30 \mathrm{~m}-70 \mathrm{~m})$ had the highest biomass followed by the land adjoining stratum, $\mathrm{S} 1(10 \mathrm{~m}-30 \mathrm{~m})$ and the least stratum biomass was obtained from the farthest stratum, S3 $(70 \mathrm{~m}-100 \mathrm{~m})$. Fishing is optimized in the middle stratum, S2.
\end{abstract}

(C) 2011 International Formulae Group. All rights reserved.

Keywords: Biomass estimate, finfish communities, demersal trawl, Atlantic Ocean, Badagry coast, Nigeria.

\section{INTRODUCTION}

Estimates of abundance are pertinent for fisheries management purposes, and the demand for such information has increased dramatically in recent years. Indices of population dynamics such as abundance, mortality rates and recruitment are required for quantitative understanding of ecological processes and are integral parts of the knowledge for an effective fishery management. Abundance surveys will always play a major role in evaluating the relative importance of environmental influences, interspecies and intra-specific relationships as well as the possible density - dependent effects in regulating population size. In many ways, the accuracy with which population sizes can be determined ultimately defines our ability to test a desired ecological hypothesis in the field.

Research survey of the fish resources of the Nigerian coastal waters dates back to the 1960s (Longhurst, 1965; Williams, 1968). Surveys in the early 1970 s led to the establishment of the shrimp fishery, since then there had been several other research surveys for the assessment of the fish stocks in Nigerian waters from which deep-water resources surveys led to the identification of Ariomma bondi, an important drift fish species 
in the Nigerian waters which is still not harnessed.

The management of Nigeria's living marine resources onto wards is based on scientific data provision, but with the shortfall in data availability due to lack of regular and periodic surveys, the fishery managers are ill equipped to implement prescribed solutions to a potential fishery problem.

Fishing on the Lagos end of the Nigerian coastal waters is conducted mainly in shallow waters by mostly artisanal fishers and as well as commercial trawler operators. The sea fisheries (Fishing) Regulation S.I. 19 Of 1992 under section 14 (1) states “ No motor fishing boat (except canoes) shall fish within the first five nautical miles of the waters of the Nigerian continental shelf" but over the years, there has been conflicts between the two groups of fishers arising from artisanal fishers' nets being entangled in trawl lines. The industrial trawlers do most of their fishing at depths shallower than the $100 \mathrm{~m}$ depth area probably due to lack of capacity and also inadequate information on the available stock.

The result from this survey is aimed at providing a more recent and accurate data for fishery managers and policy makers alike on how best to manage Nigeria fishery resources as well as providing an insight into the ecological dynamics in the Badagry fishing area (Figure 1).

\section{MATERIALS AND METHODS}

The survey was carried out using the otter trawler F.T. Susainah (LOA 25, capacity $540 \mathrm{Hp})$. The fishing gear used was a commercial otter board high opening trawl. The mesh in the cod-end was $20 \mathrm{~mm}$ and the wing spread was $18.5 \mathrm{~m}$. The average haul duration was 30 minutes and towing speed varied between $2.4-2.7$ nautical miles per hour. All hauls were made during the day. The catch was sorted into species and species groups as reported by Sparre and Venema (1992) and then length - frequency data was taken before being put in labeled bags and stored in the refrigerator for onward transporting to the laboratory in the Institute for identification collection of biological information (length, weight, stomach content analysis etc). This report is an excerpt from the first ten days of the Living Marine Resources Survey (LIMARES).

The selection of trawl stations followed a stratified random sampling which was depth dependent along transects. There was no fixed distance between stations but they were of 10 $\mathrm{m}$ depth apart. The stations were at 10, 20, 30, 40, 50, 70 and $100 \mathrm{~m}$; this helped in reducing variance of biomass estimate (Figure 2).

The entire study area was divided into three strata, S1 (shallow water of $<30 \mathrm{~m}$ depth), S2 (medium depth water of $>30 \mathrm{~m}$ and $<70 \mathrm{~m}$ ), and S3 (deep water ranging $>70$ and $\leq 100 \mathrm{~m}$ ). The combined catch per unit effort (CPUE) for all finfish species in a stratum was used to calculate catch per unit area (CPUA) and subsequently used for biomass estimation for that stratum by means of the swept area method (holistic approach to stock assessment).

The catch rate or CPUE $\left(\mathrm{Kghr}^{-1}\right)$ of haul and CPUA $\left(\mathrm{KgKm}^{-2}\right)$ were calculated for each species and summed up for their respective families. Biomass estimates of selected families were computed using the swept area method. This method assumes that the mean catch in weight per unit area is an index of stock abundance (Gulland, 1969, Pauly, 1984). The area, a, swept by the trawl is calculated as

$$
\mathrm{a}=\mathrm{D} \times \mathrm{W}\left(\mathrm{Km}^{2}\right)
$$

where, $\mathrm{D}$ is the distance covered by the trawl during a haul and $\mathrm{W}$ is the path swept by the trawl.

The biomass (B) for entire area is calculated by summing up biomass in strata $\mathrm{S} 1, \mathrm{~S} 2$, and S3. Biomass, B for each stratum is estimated as

$$
\mathrm{B}=\mathrm{A}_{\mathrm{si}} \times\left(\text { mean CPUA/X) Where, } \mathrm{A}_{\mathrm{si}}\right.
$$
is entire area of the stratum under $\mathrm{V}$ consideration, and $\mathrm{i}=1,2,3 \ldots \mathrm{nth}$, while $\mathrm{X}$ being a technology -related parameter which represents the proportion of individuals of stock caught per unit of effort exerted (Gulland, 1983) otherwise referred to as catchability co-efficient and for the purpose of this report we are assuming $X$ to be 1 . 


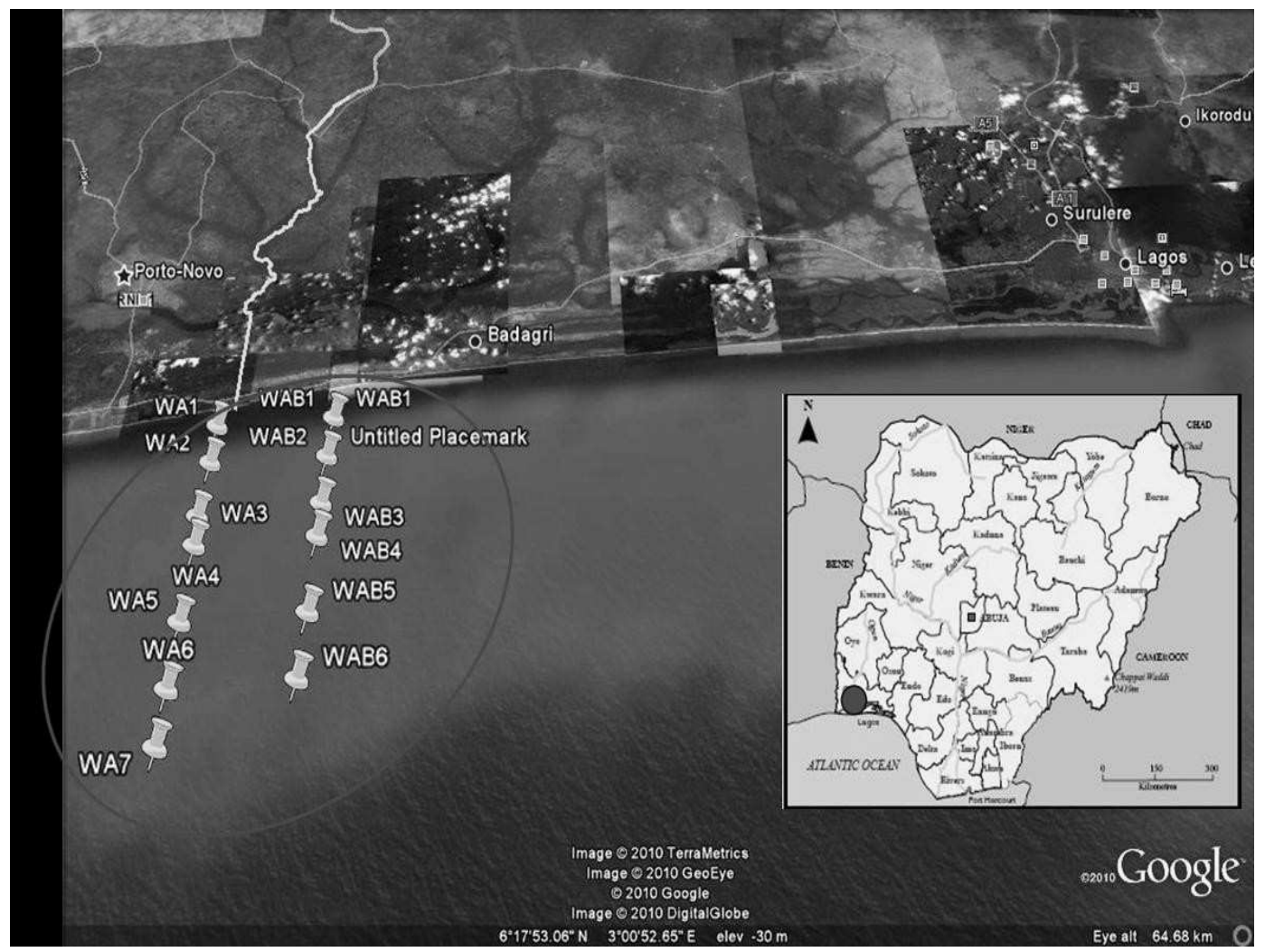

Figure 1: A satellite imagery of Badagry coast, Nigeria showing the sampling stations (enclosed in the circle). Inset is the map of Nigeria showing the location of Badagry in Lagos State.

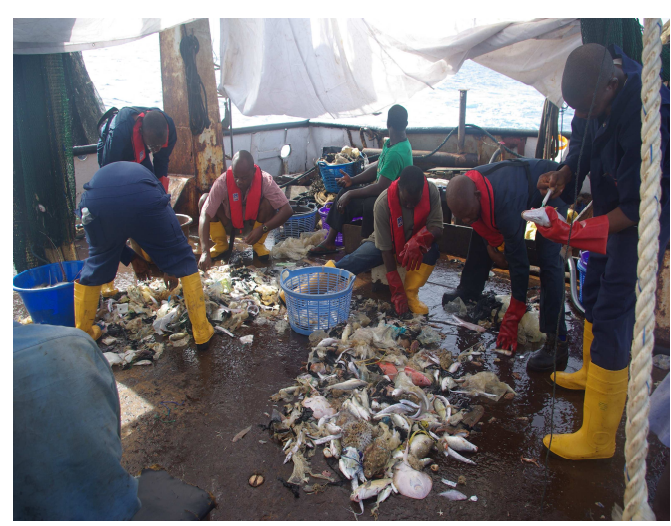

(a)

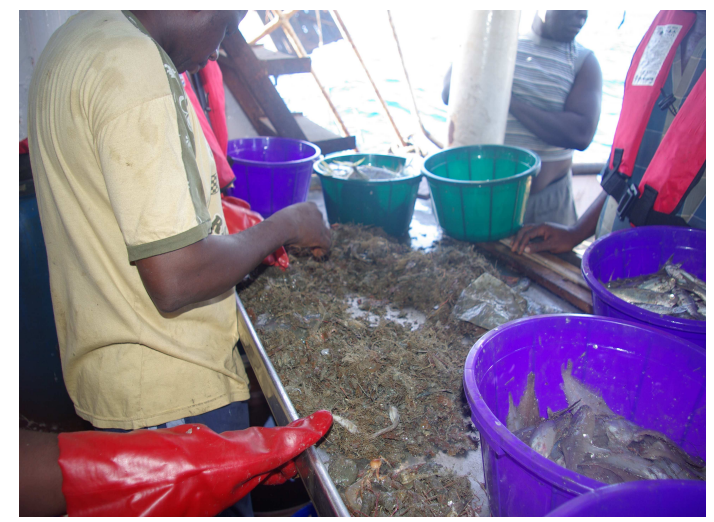

(b)

Figure 2: (a) Photograph of a cross section of scientists sorting the landings on deck FT. Sussainah; (b) scientists taking length-frequency measurements of sorted species on the sorting table. 


\section{Statistical analysis}

It was assumed that all sampling stations were randomly selected. The CPUE and CPUA values were $\log$ transformed to base e and the resultant data was used to produce a geometric mean. The mean and standard deviation was calculated by back transforming the mean on the log scale by the exponential function. (e.g. Mean CPUA = EXP (mean CPUA ${ }_{\log \text { scale }}+$ variance CPUA ${ }_{\log }$ scale/2) (Daug et al., 2002). The mean errors were tested at $\mathrm{P}=0.05$ using students distribution to obtain the confidence limits for the obtained results.

\section{RESULTS}

\section{Species and family distribution}

The study observed ninety-seven finfish species coming from fifty-six families. The stations had finfish species numbers as shown in Table 4. The species with the least landings were Ariomma bondi; Ariommatidae, Chaetodon marcellae; Chaetodontidae, Sardinella aurita; Clupeidae, Aluterus heudelotti; Monacanthidae, Cynopuncticus ferox; Muraenidae, Hippocampos; Syngnathidae, and Zeus faber; Zeidae occurring $0.0122 \%$ by weight of total landings. The species with the most was Brachydeuterus auritus; Haemulidae having $0.11 \%$ by weight of total landings. Table 1 shows the list of some species and their distribution range.

\section{Catch rates}

Catch rates for all the finfish families in the study area showed Haemulidae to have the highest catch rates of $7.64 \mathrm{Kghr}^{-1}$ followed by Scianidae with $6.51 \mathrm{Kghr}^{-1}$ and of the commercially important finfish families, the least CPUE is observed in the Tetraodontidae with $1.8 \mathrm{Kghr}^{-1}$. The coefficient of variation of the CPUE of the commercially important families in the study area ranged from $3 \%$ to $267 \%$ (Table 2).

\section{Biomass estimates}

The family with the most biomass estimate in the entire study area is Haemulidae having about sixteen tons, followed by scianidae, thirteen tons and the least is Tetraodontidae, about five tons amongst the economically important families enumerated. The CPUE and CPUA of these families are given in Table 2.

The stratum S3 had the least biomass estimate of all species combined, 80 tons, and S2 had the most, 144 tons while the stratum adjoining land was next to $\mathrm{S} 2$ with 136 tons, with respect to the commercially identified finfishes. Table 3 presents mean CPUA of the strata with their confidence limits. The areas of the strata are $133.7 ; 138$ and $151 \mathrm{Km}^{2}$ for $\mathrm{S} 1$; S2; and S3 respectively. Total biomass estimates are gotten by multiplying MCPUA by the corresponding area of the stratum.

Table 1: List of commercially important species and their distribution range.

\begin{tabular}{llc}
\hline Family & Species; Common name & Depth range found (m) \\
\hline Serranidae & Serranus accraensis, Ghanean comber & $70 \leq \mathrm{X} \leq 50$ \\
& Epinephelus aeneus, White grouper & $100 \geq \mathrm{X} \geq 20$ \\
& Anthias anthias, Swallowtail seaperch & $70 \geq \mathrm{X} \geq 40$ \\
& Epinephelus gauza, Dusky grouper & $\mathrm{X}=100$ \\
Sparidae & & \\
& Dentex congoensis, Congo dentex & $100 \geq \mathrm{X} \geq 20$ \\
& Dentex angolensis, Angola dentex & $100 \geq \mathrm{X} \geq 60$ \\
& Pagellus bellotis, Red pandora & $50 \geq \mathrm{X} \geq 40$ \\
Tetraodontidae & $\mathrm{X}=30$ \\
& Pagrus caruelosticus, Blue spotted seabream & $50 \geq \mathrm{X} \geq 10$ \\
& & $30 \geq \mathrm{X} \geq 10$ \\
& Lagocephalus laevigatus, Smooth puffer & \\
& Ephippion guttifer, Prickly puffer &
\end{tabular}




\begin{tabular}{|c|c|c|}
\hline & Sphoroides mamoratus & $100 \geq X \geq 30$ \\
\hline Trichiuridae & Trichiurus lepturus, Largehead hairtail & $50 \geq X \geq 10$ \\
\hline \multicolumn{3}{|l|}{ Bothidae } \\
\hline & Syacium micrurum, Channel flounder & $70 \geq X \geq 30$ \\
\hline & Bothus podas africanus, Wide eyed flounder & $X=30$ \\
\hline & Citharichthys stamflii, Smooth flounder & $70 \geq X \geq 30$ \\
\hline & Arnoglosus capensis, Cape scad fish & $X=50$ \\
\hline \multicolumn{3}{|l|}{ Cynoglossidae } \\
\hline & Cynoglossus brownii, Nigerian tonguesole & $50 \geq X \geq 10$ \\
\hline & Cynoglossus monodi, Guinean tonguesole & $\bar{X}=10$ \\
\hline & Cynoglossus sengalensis, Senegalese tonguesole & $30 \geq X \geq 10$ \\
\hline \multicolumn{3}{|l|}{ Haemulidae } \\
\hline & Brachydeuterus auritus, Bigeye grunt & $70 \geq X \geq 10$ \\
\hline & Pomadasys jubelini, Sompat grunt & $20 \geq X \geq 10$ \\
\hline & Pomadasys peroteti, Parrot grunt & $X=50$ \\
\hline \multicolumn{3}{|l|}{ Carangidae } \\
\hline & Selene dorsalis, African moonfish & $50 \geq X \geq 10$ \\
\hline & Caranx hippos, Crevalle jack & $40 \geq X \geq 10$ \\
\hline & Chloroscombrus chrysurus, Atlantic bumper & $30 \geq X \geq 10$ \\
\hline & Selar crumenophthalmus & $70 \geq X \geq 30$ \\
\hline & Decapterus punctatus, Round scad & $X=70$ \\
\hline & Alectis alexandrinus, Alexandria pompano & $40 \geq X \geq 10$ \\
\hline \multicolumn{3}{|l|}{ Polynemidae } \\
\hline & Pentanemus quinquarius, Royal threadfin & $30 \geq X \geq 10$ \\
\hline & Galeoides decadactylus, Shiny nose & $50 \geq X \geq 10$ \\
\hline \multicolumn{3}{|l|}{ Scianidae } \\
\hline & Pseudotolithus epipercus, Guinea croaker & $X=10$ \\
\hline & Pseudotolithus senegalensis, Cassava croaker & $40 \geq X \geq 10$ \\
\hline & Pseudotolithus typus, Longneck croaker & $\mathrm{X} \leq 20$ \\
\hline & Pteroscion peli, Boe drum & $X=40$ \\
\hline & Pseudotolithus elongatus, Bobo croaker & $X=20$ \\
\hline & Pseudotolithus brachygnatus, Jaw croaker & $X=20$ \\
\hline & Umbriana canariensis, Canary drum & $X=50$ \\
\hline & Pentheroscion mbizi, Blackmouth croaker & $X=50$ \\
\hline
\end{tabular}

Table 2: Biomass estimates and co-efficient of variation of some commercially important demersal finfish families around Badagry, Nigeria.

\begin{tabular}{lcccc}
\hline Family & $\begin{array}{c}\text { CPUE } \\
(\mathbf{K g} / \mathbf{H r})\end{array}$ & $\begin{array}{c}\text { CPUA } \\
\left(\mathbf{K g} / \mathbf{K m}^{\mathbf{2}}\right)\end{array}$ & $\begin{array}{c}\text { Biomass } \\
\text { estimate (Kg) }\end{array}$ & $\begin{array}{c}\text { Co-efficient of } \\
\text { variation (\%) }\end{array}$ \\
\hline Tetraodontidae & $1.80(4.57)$ & $11.47(8.25)$ & 4960.8 & 3 \\
Cynoglossidae & $3.32(4.26)$ & $15.73(4.26)$ & 6803.1 & 135 \\
Bothidae & $2.59(2.52)$ & $12.28(2.52)$ & 5310.1 & 266 \\
Sparidae & $2.65(1.96)$ & $13.28(2.19)$ & 5743.1 & 190 \\
Serranidae & $2.33(1.44)$ & $11.01(1.44)$ & 4765.2 & 158 \\
Trichiuridae & $4.33(3.50)$ & $20.50(3.50)$ & 8866.0 & 195 \\
Polynemidae & $4.83(2.96)$ & $22.88(2.96)$ & 9895.7 & 165 \\
Carangidae & $4.67(4.12)$ & $22.09(4.12)$ & 9555.4 & 204 \\
Scianidae & $6.51(3.61)$ & $30.83(3.61)$ & $13,333.1$ & 158 \\
Haemulidae & $7.64(7.50)$ & $36.19(7.50)$ & $15,651.7$ & 267 \\
\hline
\end{tabular}

* Values in parenthesis are variances of means 
Table 3: Mean CPUA of demersal finfish sampled around Badagry, Nigeria.

\begin{tabular}{lcccccc}
\hline Stratum & $\begin{array}{c}\text { No. of } \\
\text { hauls }\end{array}$ & Mean CPUA & $\begin{array}{c}\text { Standard } \\
\text { deviation }\end{array}$ & $\begin{array}{c}\text { Standard } \\
\text { error }\end{array}$ & $\mathbf{t}_{\mathbf{0 . 5}}(\mathbf{n}-\mathbf{1})$ & $\begin{array}{c}\text { confidence } \\
\text { limits }\end{array}$ \\
\hline S1 & 6 & 1017.1 & 414.2 & 169.1 & 2.577 & $1071.1 \pm 435.8$ \\
S2 & 4 & 1045.0 & 1432.8 & 716.4 & 3.182 & $1045 \pm 2279.6$ \\
S3 & 3 & 527.6 & 56.1 & 32.4 & 4.303 & $527.6 \pm 139.4$ \\
\hline
\end{tabular}

Table 4: list of stations showing number of finfish species found.

\begin{tabular}{lccccccccccccr}
\hline Stations & A1 & AB1 & A2 & AB2 & A3 & AB3 & A4 & AB4 & A5 & AB5 & A6 & AB6 & A7 \\
\hline No. of species & 22 & 19 & 23 & 28 & 28 & 27 & 17 & 19 & 25 & 20 & 27 & 27 & 21 \\
\hline
\end{tabular}

\section{DISCUSSION}

Hubbell (2001) reported that diversity indices combined with the number of species (species richness) are an attribute of the community related to historical factors; species abundance which is an attribute of the population determined by the reproductive potential and survival rates of each species; and population regulatory interactions, it is with this in mind that we looked into the finfish community in the this survey. The Scianiids were the most diverse family having eight species covering a depth range of $10-$ $50 \mathrm{~m}$, followed by the Carrangiids having six species covering a depth range of $10-70 \mathrm{~m}$. Serraniids, Spariids and Bothiids had 4 species while Haemuliids, Tetraodontiids and Cynoglossiids had three species. Polynemiids and Trichiuriid had two and one species respectively. This implies that the trawler landings especially from the middle stratum, $\mathrm{S} 2$ is likely to be better in terms of biomass as well as in composition of commercially important species than either of S1 or S3 strata, this is possible due probably to the finfish community composition which may comprise mostly of scianiids, carrangiids, serraniids, spariids and bothiids which are dominate the population. This is line in with the report of Longhurst (1965) where he identified the Scianiids as constituting about $40 \%$ of marine landings in West Africa where Nigeria belongs. Catch distribution of many species can be heavily skewed due to few large catches resulting from schooling behavior. In such instances, one or two large catches can often inflate the value of the catch per unit effort of samples thereby resulting in a false characterization of the true relative abundance of species. The difference in the relative abundance of the finfish communities could be as a result of schooling behavior of the species. There were differences in biomass estimates amongst the strata, even though the number of hauls per stratum varied (Table 3 ), the middle stratum had 4 hauls and yet the largest mean catch per unit, followed by the first stratum, S1 which had the largest number of hauls and lastly, S3 having the least mean catch per unit area and also the least number of hauls. Diversity with respect to family and species classification is dominated by $\mathrm{S} 1 ; \mathrm{S} 2$; and S3 having 41, 67; 33, 48; and 30, 41 families and species respectively. The S3 stratum did not register the presence of Cynoglossiids, Polynemiids, Trichiuriid and Scianiids, this probably, is indicative of depth specific habitation and could be due mainly to substrate type and hydrography of the environment (Bainbridge, 1964; Longhurst, 1965). The genus Ariomma found in that stratum was seen as a seasonal species (Personal communication). The stratum S3 which had the least biomass might have resulted from the absence of some species which constituted most of the catch in the other two strata and also probably due to the number of hauls. The first five nautical miles 
covers the entire area of stratum $\mathrm{S} 1$ and also the first stations in S2. This implies that most fishing activities will be expected to be carried out on $\mathrm{S} 2$ considering the fact of its having the largest mean CPUA.

Biomass estimates for trawl fisheries based on mean catch from gear swept-area often result in enormous bias due to the dependency of effective trawl durations on oceanographic factors including water depth as reported by Krieger and Sigler (1996). Somerton et al. (1999) also, reported possible herding effects that can affect biomass estimates. This technique assumes constant swept areas for pre-set tow durations and also, captures inefficiencies independence of water depth and other hydrodynamic conditions. However, towing velocities also vary with bottom type and currents, resulting in enormous biases, often more pronounced in fisheries with wide depth variations. In this report, the hydrodynamic conditions were assumed to be constant throughout the sampling space, hence due consideration for differences arising from catch rates only are discussed. The results (Table 2) showed a wide range of variability (3\% - 267\%), which agrees with the work of Daug et al. (2002), that reported high level of co-efficient of variation. Haemulidae, the family with the highest CPUA, with the highest biomass estimate had a corresponding high C.V., Tetraodontidae has the least C.V. and also a correspondingly low CPUA, hence statistically, a better estimate than that of Haemulidae.

There is a dearth of information on the biomass of species in Nigerian coastal water. This information when available will enhance management of the fisheries as well as biodiversity conservation through ecosystem approach to fisheries management.

In the same vane a critical look at the deep water resources might establish a new fishery. Ariomma bondi has the potential of being canned and as such a potential foreign exchange earner, this can be harnessed by the trawler operators instead of competing with artisanal fishers on the nursery grounds. Due mainly to logistics, a maximum sustainable yield (MSY) could have been estimated for the study area if on the average the entire seasons were sampled. This probably accounts for the conflict between artisanal fishers and industrial trawlers. If the industrial trawl operators are to move further to the third stratum, S3, this therefore means that more effort will be expended by the commercial trawler operators to obtain enough to sustain their operation, hence, accounts probably for their reduced activity in the deeper waters.

In conclusion, it will be necessary to advice agency responsible for the fishery regulation to either amend the distance/depth to read "which ever that comes first, either the 5 nautical miles or the $50 \mathrm{~m}$ depth should be the limit of the artisanal fishers" to minimize conflict with the industrial fishers.

\section{ACKNOWLEDGEMENTS}

The authors are much grateful to $\mathrm{Mr}$. Imhansoloeva of the department of Marine, Geology/Geophysics, NIOMR for helping out with the map and also Mr. E.E. Edet Assistant Director (HOD) Federal Department of Fisheries, Lagos State for his input on the problems of the artisanal fishers.

\section{REFERENCES}

Bainbridge V. 1964. The zooplankton. In The Coastal Oceanography of Western Nigeria. Longhurst AR (Ed.). Bulletin de l'Institut Fondamental d'Afrique Noire, Sciences Naturelles, 26(2): 390 - 402.

Daug VT, Tran D, Nielsen Riget RF. 2002. Naga, The ICLARM Quarterly Vol. 25, No. 1 January-March 2002

FAO. 1992. Review of the state of World Fishery Resources. Part 1: The Marine Resources. FAO Fisheries Circular, Rev. 8, Part 1.114 pp.

Gulland JA. 1969. Manual of Methods for Fish Stock Assessment. Part 1: Fish Population Analysis. FAO Manual of Fishery Sciences, (4): 154p

Gulland JA. 1983. Fish Stock Assessment: A Manual for Basic Methods. Wiley: New York, USA; 223p. 
Hubbell S. 2001. The Unified Neutral Theory of Biodiversity and Biogeography. Princeton University, Princeton: New jersey, USA.

Longhurst AR. 1965. A survey of the fish resources of the Eastern Gulf of Guinea. J. Cons. Int. Explor. Mer., 29: 302-334.

Oosthuizen A, Sauer WHH, Augustyn CJ. 2007. Developing a policy and operational protocol for the formation of new commercial fisheries in South Africa. African Journal of Marine Science, 29(3): 393-401.

Pauly D. 1984. Fish population dynamics in tropical waters: a manual for use with programmable calculators. ICLARM Stud. Rev., 8: 325.

Pauly D, Gayanilo FC Jr. 1997. A Bee: An Alternative Approach to Estimating the Parameters of a Length-Weight Relationship from Length-Frequency
Samples and their Bulk Weights. ICLARM: Manila, Philippines.

Somerton D, Lanelli J, Walsh S, Smith S, Godo OR, Ramm D. 1999. Incorporating experimentally derived estimates of survey trawl efficiency into the stock assessment process: a discussion. ICES Journal of Marine Science, 56: 299-302.

Sparre P, Venema SC. 1992. Introduction to tropical fish stock assessment. Part 1: Manual. FAO Fisheries Technical Paper, 306/1, Rev 1.

Williams F. 1968. Report on the Guinean trawling survey (Vol. 1). Publication of African Unity Science Technical Resource Communication (99); 828p. 